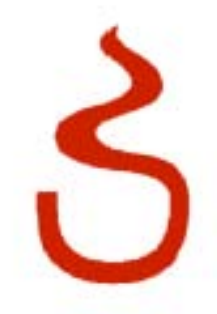

DRUID

Paper to be presented at the Summer Conference 2010

on

, June $15-18,2010$

\title{
Technology Market Intermediaries and Innovation
}

\author{
Frank Tietze \\ Hamburg University of Technology (TUHH), Institute for Technology and Innovation Management \\ f.tietze@tuhh.de \\ Cornelius Herstatt \\ Hamburg University of Technology (TUHH), Institute for Technology and Innovation Management \\ c.herstatt@tuhh.de
}

\section{Abstract:}

On the markets for technology (MfT) we currently observe a sizable growth, observe that firms still face immanent transaction obstacles and the emergence of technology market intermediaries (TMI). Why TMIs emerge and how they attempt to facilitate transactions however is not yet sufficiently understood.

For these two questions we propose theoretical explanations within this paper building primarily on the arguments of Stigler (1951), North (1996) and Williamson (1979). Throughout this argumentation we combine the two related levels of analysis. We take into account the dynamics on market level and the micro level of the firm with regard to IP transactions in which firms are involved when pursuing open innovation.

We argue that the growing MfT on the one hand and immanent transaction obstacles on the other hand create business opportunities for entrepreneurs to develop new transaction models (service innovations) offered by TMIs as a new type of market actor (organizational innovation) to support firms managing transactions. Following the notion of Stigler (1951) and North (1996), the emergence of TMIs as organizational innovation has an impact on the way how transactions were 'traditionally managed and thus creates an institutional change that leads to further division of labor on the MfT.

Following Williamson (1979) we propose that new transaction models developed by TMIs aim to commoditize the traditionally idiosyncratic governance structures making transactions more economically. However, it remains to be seen which of the newly developed models will survive and deliver more economic transactions contributing to further developments towards efficient markets. 


\title{
Technology Market Intermediaries and Innovation
}

- Why they emerge and how they facilitate transactions

\begin{abstract}
On the markets for technology (MfT) we currently observe a sizable growth, observe that firms still face immanent transaction obstacles and the emergence of technology market intermediaries (TMI) developing novel models (e.g. IP auctions, patent aggregation funds) aiming to facilitate more economical market transactions of e.g. technologies, technical knowledge, intellectual property (IP) and particularly patents. Why do TMIs emerge and how do they attempt to facilitate IP transactions however is not yet sufficiently understood.

For these two questions we propose theoretical explanations within this paper building primarily on the arguments of Stigler (1951), North (1996) and Williamson (1979). Throughout this argumentation we combine the two related levels of analysis. We take into account the dynamics on market level and the micro level of the firm with regard to IP transactions in which firms are involved when pursuing open innovation.

We argue that the growing MfT on the one hand and immanent transaction obstacles on the other hand create business opportunities for entrepreneurs to develop new transaction models (service innovations) offered by TMIs as a new type of market actor (organizational innovation) to support firms managing transactions. Following the notion of Stigler (1951) and North (1996), the emergence of TMIs as organizational innovation has an impact on the way how transactions were 'traditionally' managed and thus creates an institutional change that leads to further division of labor on the MfT. Following Williamson (1979) we propose that new transaction models developed by TMIs aim to commoditize the traditionally idiosyncratic governance structures making transactions more economically. For instance IP auctions implement more standardized legal frameworks (e.g. lump sum payments - no royalties, fees) in order to diminish transaction costs. However, it remains to be seen which of the newly developed models (or those to come) will survive and actually deliver more economic transactions and thus contribute to further developments towards efficient markets.
\end{abstract}




\section{Introduction}

To create continuous growth firms increasingly focus on the more efficient creation of innovation. To continuously innovate it is essential for firms to innovate most economically. Innovation is increasingly understood as a cumulative, dynamic process where firms assemble a variety of pieces of complementary technical know-how (tacit and explicit) as well as IP assets from different sources.

An increasing number of firms attempts to achieve this by acquiring and exploiting technologies and patents in particular from beyond the own firm boundaries ${ }^{1}$ as it can be more economically (less resource consuming, cheaper or faster) than internal technology development. However, today still many obstacles prevent efficient IP transactions with external actors. For firms it is thus essential to understand whether new approaches (e.g. online market places, patent value funds, auctions) to acquire and exploit IP can serve their purpose.

In order to develop innovation more cost-effectively the market frameworks need to facilitate enhanced resource allocation so as to effectively match those market actors owning technologies (and the related IPRs) with the actors who possess the necessary complementary resources. The newly emerging TMIs $^{2}$ aim to support this development, but however are insufficiently understood. With this paper we propose an explanation why TMIs currently emerge on the markets for technology (MfT) and how they impact IP transactions.

This paper is structured as follows. The next section discusses the relationship of innovation beyond the boundaries of the firm and IP transaction. The second section of this paper provides more detailed evidence about the three phenomena that we currently observe on the MfT. We build on these empirical observations in the third part of the paper where we propose two argumentations. Firstly, we propose an explanation addressing the question 'why TMIs are currently emerging' referring mainly to the 'classical' arguments of Stigler (1951) and North (1996) taking into account the dynamics on market level (MfT) and the micro level of the firm with regard to IP transactions in which firms are involved when pursuing open innovation. Secondly, we turn to the question 'how TMIs impact the management of transactions' using mainly the argumentation provided by Williamson (1979). The final section concludes the paper.

\footnotetext{
${ }^{1}$ Penrose (1951) is well recognized to have contributed substantially to the theory of the firm. For recent discussions about the boundaries of the firm see e.g. Arora and Merges (2004), Holmström and Roberts (1998) and Terwiesch and Ulrich (2008)

${ }^{2}$ We define TMIs based on a literature review as "private firms specialized in intellectual property that provide services to primarily technology based firms in order to facilitate the external exchange of intangible assets, predominantly without adding value or holding property of the asset, excluding services provided typically by patent law firms (e.g. all services related to the patent application procedures and patent litigation court cases).” Thus, our definition focuses on private firms and excludes government support vehicles and TTOs set up by universities as well as patent law firms offering their 'classical' legal services (e.g. patent filing, prosecution and litigation). The term intermediary stems from the financial economics literature. Cf. e.g. Gorton and Winton (2002) and Engerman (2003).
} 


\section{Innovation and IP transactions}

While firms have currently recognized the increased importance to continuously innovate, at the same time they are pressed by shortening technology, development and product life cycles for products are characterized by increasing technical complexity. Lichtenthaler (2005), referring to Cesaroni, Gambardella et al. (2004), Granstrand (2004), Chesbrough (2003) and Grindley and Teece (1997) argued that the increasing technological content of products has been intensified by a growing knowledge convergence and fusion, which have led to higher numbers of knowledge components from different areas being incorporated into a single product. According to Granstrand (2000, p.9) "products and services become not only increasingly based on new technologies, but increasingly based on many different technologies. That is, products and services [have?] become more multi-technological.” These developments make it merely economically impossible for a single firm to internally develop all technologies necessary for a product and particularly the IPRs required to enable freedom-to-operate in order to prevent costly litigation. ${ }^{3}$

At the same time, firms often undertake redundant research. If firms could assess technologies that were already developed by other market actors they could innovate more economically, wherefore an increasing number of firms is opening up their innovation processes beyond the own firm boundaries. ${ }^{4}$ Particularly if innovation is understood as a cumulative, dynamic process ${ }^{5}$ where firms assemble 'pieces' of complementary technical know-how (tacit and explicit) as well as IP assets ${ }^{6}$, it becomes obvious that firms can innovate more economically if these 'pieces' could be acquired from different sources no matter whether they come from inside the own firm (including other business units) or

\footnotetext{
${ }^{3}$ Known and discussed in the literature under the notion 'IP assembly problem' e.g. by Granstrand (2003, p.59), who argued that "intellectual property rights to sustain a business become increasingly fragmented among players."

${ }^{4}$ Parker et al (1996) noted that the high cost of internal R\&D had encouraged firms to turn to independent inventors. Moreover, firms who intentionally or unintentionally find that their internal R\&D efforts are limited to line extensions and marketing can gain access to the breakthrough ideas created by inventors who are not confined to the corporate context. More recently, Quinn (2000) highlighted the outsourcing of innovation. Rigby and Zook (2002) also argued for taking an 'open market' approach to innovation, which includes actively seeking inventions from external sources.

${ }^{5}$ According to Pénin (2008) similar concepts discussed in the literature are 'step-by-step innovation', 'multi-invention products', 'sequential innovation' and 'collective mode of innovation'. Murray and O’Mahony (2007, p.1008) argued that "for innovation to occur...innovators must have the ability to actually combine or accumulate knowledge." According to Powell and Snellman (2004), our economy is increasingly reliant on the production, refinement, and accumulation of ideas. Aghion, Harris et al. (2001, p.470) argued along the lines of Harris and Vickers (1987) and Budd, Harris et al. (1993) that “technological progress as emerging from a dynamic process of 'step-by-step' innovation” and noted that in Schumpeterian (i.e. evolutionary) economics growth models innovation is often modelled as a 'step-by-step' concept. Green and Scotchmer (1995, p.20) noted that "knowledge and technical progress are cumulative in the sense that products are often the result of several steps of invention, modification, and improvement.” Already Schmookler (1966, p.vii) indicated the cumulative nature of technical knowledge for inventions as "the 'bits' that are added to the existing stock of knowledge.” The cumulative nature of innovation has further been subject to research in relation to the policy debate concerning optimal patent breadth e.g. by Scotchmer (1991), Green and Scotchmer (1995), Chang (1995), O'Donoghue (1998) and Mazzoleni and Nelson (1998).

${ }^{6}$ When 'technology' is understood as assembly of those three elements that enables a technical purpose. The dichotomy of tacit and explicit knowledge has been introduced by Polanyi (1966). Rather more generically technology can be understood as defined by Schmookler (1966), i.e. as "the social pool of knowledge of the industrial arts. Any piece of technological knowledge available to someone anywhere is included in this pool by definition.”
} 
from other market actors outside the own firm's boundaries (e.g. other firms including start-ups, universities, lead users or independent inventors). ${ }^{7}$ To limit the effect of ever increasing product development costs firms have recognized that one might acquire technologies more economically from the markets ${ }^{8}$ than developing them on its own. For instance, technologies could be actively used by their inventors but need to be embedded into other firms' products because they have been established as an industry standard (e.g. Bluetooth interfaces in cell phones). Such technologies can be acquired (e.g. in-licensed or purchased) to avoid redundant R\&D. Multinational corporations might even acquire SMEs and start-ups solely for such purpose and integrate them into the own operations. For instance, if a university spin-off has developed a science based technology ready to be embedded into new products, such strategic choice can be more economically than developing the technology again.

At the same time certain technologies of a firm's own technology portfolio might be beneficial for other firms. Although a firm's 'willingness-to-exploit' (e.g. out-license or sale) can differ across technologies because technologies serve different (strategic) purposes in a portfolio. For instance, while technologies directly related to a firm's core competences and competitive advantage might not be allowed for external exploitation ${ }^{9}$ - or at least not to direct competitors - other technologies might not be critical to the firm's competitive advantage and might very well be suitable for external exploitation and contribute to a higher R\&D return ration. ${ }^{10}$ Furthermore, firms might have conducted R\&D investments to develop certain technologies although these technologies are not used at all. ${ }^{11}$ At

\footnotetext{
${ }^{7}$ This understanding of innovation through external technology sourcing is not particularly new. Already Teece (1989, p.35) argued that "the institutional structure of innovation in capitalist economies is extremely variegated and involves a complex network of backward, forward, horizontal, lateral relationships and linkages within, among and between firms and other organizations...” Furthermore, Granstrand and Sjölander (1990) suggested a typology for technology acquisition and exploitation strategies. However, it took until 2003 when Chesbrough (2003) labelled the concept 'open innovation' and a wider range of firms realized the importance to open up innovation processes. Following few successful firms like P\&G nowadays firms act in wide networks trying to source ideas and IP for new products and newly developed technologies from different external sources including lead users (see e.g. Herstatt and E.v.Hippel (1998)). According to Murray and O’Mahony (2007, p.1008) “with a shift toward 'open innovation' ... contributors to innovations are more likely to come from different types of organizations (e.g. Powell, Koput et al. (1996), Owen-Smith and Powell (2003)) and across individual and firm units of analysis (Rosenkopf, Metiu et al. (2001)).”

${ }^{8}$ Various terms are used by different scholars often in an almost similar meaning. Chesbrough (2006) used the term 'markets for IP', Gambardella, Giuri et al. (2007) used the term 'market for patents', Lichtenthaler and Ernst (2006) used the term 'market for knowledge', and Gu and Lev (2000) used the term 'markets in intangibles'. The use of different terminology further indicates the absence of clear and commonly accepted definitions in this field. Although we specifically focus on 'markets for patents' few solid research can be found on this specific term with one exception being Troy and Werle (2008). Thus we apply the term 'MfT' as used by most scholars in this field including A. Gambardella, O. Granstrand and D. Harhoff. ${ }^{9}$ In the literature various terms are used for essentially similar processes. These include 'deployment' e.g. by Escher (2005) and ‘commercialization' e.g. by Lichtenthaler (2006).

${ }^{10}$ For different strategic purposes of technologies within technology portfolios cf. e.g. Tschirky and Koruna (1998, chapter 4.2.10) who presented different typologies and approaches to classify technologies.

${ }^{11}$ It is still a common assumption that along the innovation process the market actor who files for patent protection of a technical invention is the same who ultimately exploits the patented invention on the market turning it into an innovation. Empirical evidence proves that this is not the case. A dominant share of patents is not used directly by its inventors. Gambardella, Giuri et al. (2006) reported that 36\% of the patents in their 'huge' sample of EU patents are not used internally or for licensing. While about one half of these patents (18.7\%) may even assume a potentially high value as they help block competitors, the other half (17.4\%) labelled 'sleeping patents' are left virtually unexploited. The Institut der deutschen
} 
least with those technologies firms can generate additional revenues to increase its R\&D return ratio through external exploitation. ${ }^{12}$

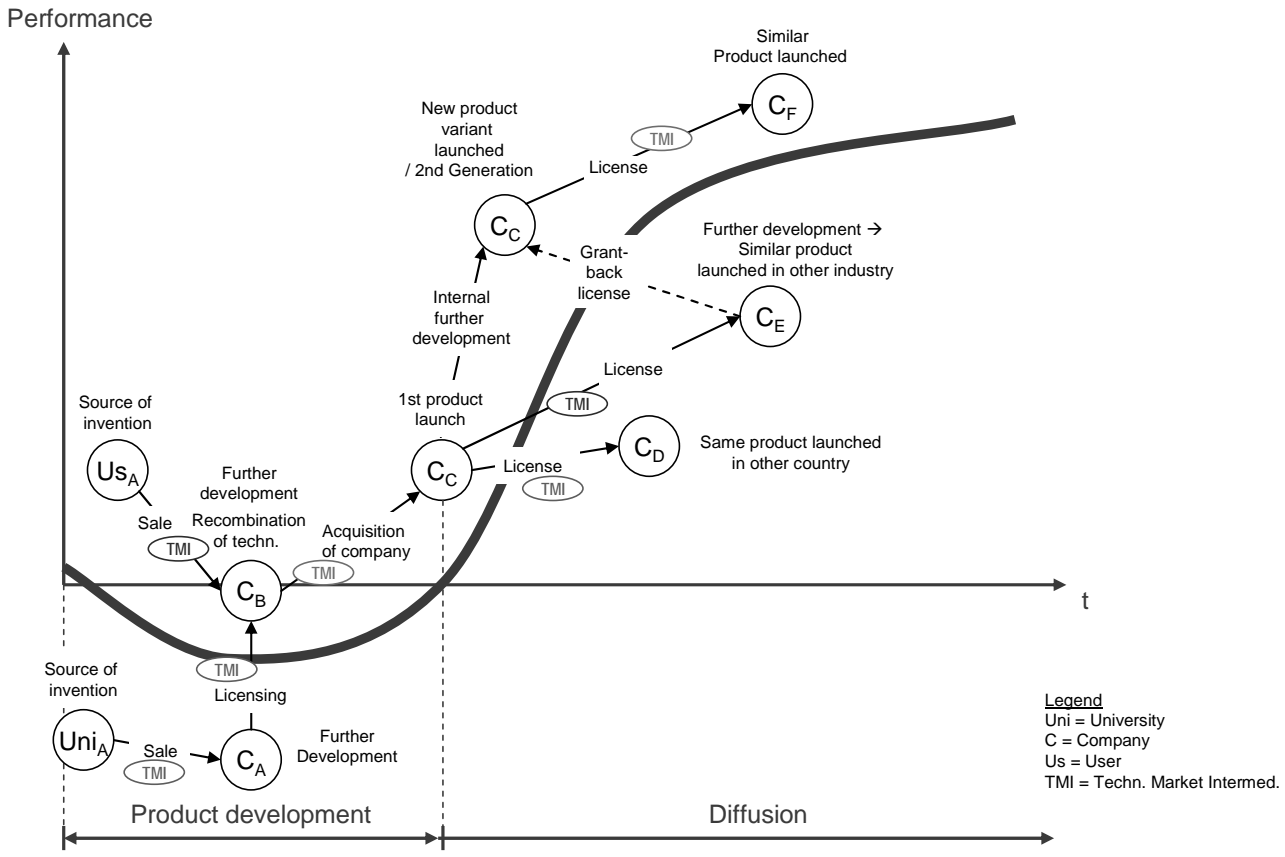

Figure 1: Example illustrating IP transactions and TMIs along the phases of an innovation process

However, when an increasing number of firms becomes increasingly outward oriented and to adapt what is often labelled as the 'open innovation' approach, those firms feel the need to establish competences to effectively and efficiently manage IP transactions along the stages of the innovation process particularly with regard to relationships with other market actors. ${ }^{13}$ Figure 1 provides an

Wirtschaft Köln (2006) proved that in Germany each fourth patent (24.6\%) is not used at all. Chesbrough (2006, p.5) reported that in the "US over 95\% of issued patents are unlicensed, and over $97 \%$ never generate any royalties."

${ }^{12}$ Bessy and Brousseau (1998, p.452) argued that "when an innovator is allowed to license his technology, he spreads it in the economic system, while at the same time he increases his return on innovation investments and efforts."

${ }^{13}$ In the 1990 s and early $21^{\text {st }}$ century many firms had realized the value of IP as corporate assets and their contribution to innovation. From 197 survey responses and 30 interviews with senior executives in the five principal regions across the world PWC (2007) reported that above $80 \%$ of all surveyed top managers agreed or strongly agreed with the statement that IP management is important to the success of the firm. Sheehan, Martinez et al. (2004) showed that compared with 10 years ago, the importance of out-licensing has grown in $51.4 \%$ of the firms surveyed by them. Furthermore, $63 \%$ of the respondents in their study expected this trend to continue and anticipate that out-licensing of patented inventions would become more important for their firms in the next five years. This expectation is confirmed as well by the survey of PWC (2007) who reported that $54 \%$ or their respondents expected a growing importance of out-licensing in the next three to five years. By today various firms have already shifted from a purely legally focused approach to administer patents towards an active IP management perceiving patents as economic assets and various IP management approaches have been developed, although they remain primarily focused on internal processes (e.g. by Edvinsson and Sullivan (1996), Sullivan (2000), Teece (2000) and Reitzig (2004). Among the most cited cases is IBM. According to Shulman (2003) and Lang (2001) IBM's licensing revenues accounted for $20 \%$ of their total profits in 1999 and in the last decade in total for almost 8.2 b€. Another example cited often is that of Dow Chemicals . According to Roos, Edvinsson et al. (1997), the firm set up an 'Intellectual Asset 
hypothetical example of different types of transactions taking place between different market actors along the innovation process. Firms that engage increasingly in open innovation thus need to acquire dedicated knowledge and management competences for external exploitation as well as acquisition of technologies, IP assets and particularly patents.

However, according to Lichtenthaler and Ernst (2006), the management approaches developed so far are still in their 'infancy'. Firms face many obstacles when managing IP transactions. Aside from internal obstacles related to management processes and firms' innovation cultures (e.g. the notinvented-here-syndrome ${ }^{14}$, valuation difficulties to assess market prices, identifying buyers) further obstacles relate to the management of inter-firm relations, the nature of technologies (and patents) as traded assets and the institutional structures. ${ }^{15}$ The many obstacles ultimately result in high transaction costs lowering the firms' incentives to engage into technology trade thus preventing the efficient diffusion and cumulative creation of innovation within networks. According to Escher (2005, p.75) "firms often fail to initiate ... an exploitation program due to market imperfections and high initial financial commitments.”

To conclude, in order to maintain competitiveness in the innovation game and to generate sustainable (endogenous) firm growth, an increasing number of firms opens up their innovation processes to exchange technologies within collaborations and networks beyond the own firm's boundaries. While on the one hand firms increasingly source technologies from other market actors through 'external technology acquisition', on the other hand they increasingly exploit own technologies outside the own firm's boundaries offering them to other markets actors. With firms' increasing activities to source and exploit technologies outside the own boundaries, the importance of IP in general and of its efficient trade on the MfT is gaining importance. Firms feel the need to manage transactions and relationships with different market actors. ${ }^{16}$ However, those transactions are still characterized by various obstacles leading to high transaction costs prohibiting efficient market clearing.

Thus, in order to develop innovation more economically the institutional frameworks need to facilitate enhanced resource allocation to match those market actors owning technologies (and the related IPRs) with the actors who possess the necessary complementary resources. The recently emerging TMIs ${ }^{17}$

\footnotetext{
Function' in 1993 and obtained licensing revenues of $110 \mathrm{M€}$ in 2000 compared to $22 \mathrm{M€}$ in 1994. One further example is provided by the Denmark-based healthcare firm Novo Nordisk A/S. According to Reitzig (2004) this firm built a dominant market position in Europe with diabetes drugs as the result of its license on a technology for manufacturing insulin from animal sources.

${ }^{14}$ For further reading about the NIH-syndrome see e.g. Lichtenthaler and Ernst (2006).

${ }^{15}$ See Scherer and Ross (1990) for an extensive elaboration of industrial structures.

${ }^{16}$ While technologies are exchanged rather in the later stages of the innovation process when products are manufactured in large scale, in the early stages of the innovation processes rather ideas are exchanged (e.g. Herstatt (2007)).

${ }^{17}$ We define TMIs based on a literature review as "private firms specialized in intellectual property that provide services to primarily technology based firms in order to facilitate the external exchange of intangible assets, predominantly without
} 
aim to support this development, but however are insufficiently understood. To better understand TMIs should be of importance for firms and innovation policy makers likewise. Firms that open up their innovation processes become increasingly involved in transactions on the MfT when acquiring and/or exploiting technologies from/to other market actors. These firms face the difficulty to decide for the most suitable transaction model among the increasing variety of the newly developed models for the trade of any technological asset. Whether new transaction models developed by TMIs diminish or even eliminate transaction obstacles, reduce transaction costs and ultimately improve the efficiency of IP transactions contributing to more economic creation of innovation should be a central question to policy makers when developing proper incentive schemes.

\section{Three phenomena - Growing MfT, transaction obstacles and the emergence of intermediaries}

On the MfT, where resources are allocated for innovation, currently we observe three phenomena which we present in the following paragraphs. Firstly, the size of the MfT has been growing recently. Secondly, transaction obstacles are still immanent and thirdly, TMIs are currently emerging as a new type of market actors (organizational innovation) that develop new models (service innovations) aiming to facilitate IP transactions.

\section{Growing Markets for Technology}

Although markets to exchange technologies and IP have existed for decades ${ }^{18}$ empirical data from various sources indicates that they have grown sizably just recently since the $1990 \mathrm{~s}^{19}$, especially in some high-technology areas. ${ }^{20}$ Arora, Fosfuri et al. (2001, p.40) compared estimates at an aggregated level from three different data sources, which were "subject to numerous caveats" but rather led to consistent results. Limiting their analysis to technological knowledge, their estimates indicated annual worldwide MfT in the range of US\$ 35-50 billion in 2000. In addition, Elton, Shah et al. (2002) and Kline (2003) estimated that the overall US patenting licensing revenues have 'skyrocketed' from below US\$ 15 billion per year at the beginning of the 1990s to around US\$ 100 billion a year in 2002.

\footnotetext{
adding value or holding property of the asset, excluding services provided typically by patent law firms (e.g. all services related to the patent application procedures and patent litigation court cases).” Thus, our definition focuses on private firms and excludes government support vehicles and TTOs (wofür steht den TTO?) set up by universities as well as patent law firms offering their 'classical' legal services (e.g. patent filing, prosecution and litigation). The term intermediary stems from the financial economics literature. Cf. e.g. Gorton and Winton (2002) and Engerman (2003).

${ }^{18}$ Even at the beginning of the $20^{\text {th }}$ century organized MfT have existed according to an extensive study by Lamoreaux and Sokoloff (1998). Just when Arora, Fosfuri et al. (2001) published their comprehensive data compilation on this topic, the phenomena started to attract attention from a wider range of scholars as well as policy makers likewise.

${ }^{19}$ To explain the reasons behind the growth effect is out of the focus of this study and remains an open question so far.

${ }^{20}$ E.g. pharma firms rely extensively on outside knowledge for their products according to Ceccagnoli, Graham et al. (2009).
} 
Results from a survey by Sheehan, Martinez et al. (2004) indicated that $81 \%$ of the responding firms expected an increasing number of out-licensing transactions from 2005 to 2010, while 54\% of the respondents have experienced a growth of out-licensing since 1995. A recent study by Institut der deutschen Wirtschaft Köln (2006) estimated that the German market for technology has a potential size of $€ 8$ billion. Gambardella, Giuri et al. (2006) estimated that the market for the EU-8 countries was $€ 9.4$ billion in 1994-1996, 12.7 in 1997-1999, and 15.6 in 2000-2002, which corresponds to $0.16 \%, 0.19 \%$, and $0.20 \%$ of the GDP, and a total growth between the third and the first period of 65\%. According to Gambardella, Giuri et al. (2006, p.V) "the total value of patents licensed has increased considerably in these industries in the 1990s, suggesting that the MfT in these sectors are growing at a significant pace.” Athreye and Cantwell (2007) have compared the growth of non-US patens and worldwide licensing receipts and came to conclude that the growth of patenting coincided with the growth of MfT after 1980s. However, the size of the MfT, i.e. for intangible assets, patents and licensing, remains difficult to determine. Besides the absence of solid measures to systematically collect data, few studies have tried to approximate the market size and so far only few official statistics are collected by international authorities (e.g. EUROSTAT) on a regular basis.

Moreover, the growth can be expected to continue in the future. Gambardella, Giuri et al. (2006) estimated that the market for technology in Europe could grow by 50\%, i.e. the potential has grown from US\$ 14.8 to US\$24.4 billion. The potential market suggests that there are notable untapped opportunities for enhancing the market for patents in Europe, and correspondingly for using this means in order to increase the rate of utilization of patents.

Other scattered evidence as well indicates the growing importance of intangible assets, IP and patents in particular. The evidence includes reports of extensive licensing revenues of few large firms, on the forefront IBM as often quoted example. ${ }^{21}$ The dynamics on the market for technology are illustrated by the controversial discussions about the abuse of the patent system appearing from enormously huge litigation cases particularly in the US but to some extent in Europe as well where 'patent trolls' recently have filed infringement cases against large firms pressing for damages and licensing royalties. $^{22}$

\footnotetext{
${ }^{21}$ While among the top patent holders in the world, its licensing revenues until 1993 amounted to approximately \$300 million a year. This changed drastically in 1993 when under the newly appointed CEO Lou Gerstner, IBM embarked on an aggressive licensing programme that he expected to yield US\$1.4 to US\$ 1.5 billion in 2000 according to (Salomon Smith Barney report on IBM, June 22, 1999). Given the substantially higher gross margin on licensing revenues than on other kinds of IBM revenues, the contribution to the bottom line of patent royalties can be regarded as considerably larger than those of other revenue sources. Thus, while IBM's royalty revenues represent about $1.5 \%$ of its 2000 total revenues, royalty income accounts for about $13 \%$ of IBM's pre-tax net income. Cf. Gu and Lev (2001)

${ }^{22}$ Various examples exist in the US. For instance, in late 2001, Research in Motion (RIM), the Blackberry manufacturer was sued by the 'non-manufacturing entity' NTP for allegedly infringing on its patents "covering the use of radio frequency wireless communications in e-mail systems.” In 2006, the case was settled with RIM paying US\$ 612.5 million to NTP. In
} 
However, despite the recently observed growth, most of the studies that were conducted to better understand technology trade on national level (e.g. Gambardella (2002), Granstrand (2004)) as well as on the micro level of the firm either from the seller (e.g. Lichtenthaler (2006), Escher (2005)) or the buyer perspective (e.g. Granstrand, Bohlin et al. (1992)) found that the market constellation, including the traded asset and the institutional structure are today far from optimal. Many obstacles are still present that inhibit markets to clear efficiently.

\section{Transaction Obstacles}

A second phenomenon that we currently observe on the MfT relates to still existing transaction obstacles. According to Troy and Werle $(2008$, p.3) the "well-functioning market for patented new technological knowledge is confronted with several obstacles knowledge ...[and the markets]... are far from functioning smoothly.” Teece (1998, p.545), referring to his early work Teece (1981), noted that almost 20 years earlier he had already recognized the "first signs for an emerging market for know-how", however at the same time had stated that "much technology does not enter it ... either because the firm is unwilling to sell or because of difficulties in transacting in the market for knowhow." Teece (1998, p.62) still noted similar circumstances, i.e. that "the market for know-how is riddled with imperfections..." and "one class of assets that is especially difficult, although not impossible, to trade involves knowledge assets.”

Ford and Ryan (1977), as one of the pioneers in this field, provided already 30 years ago a first attempt of an explanation why technology transaction opportunities are not realized by many firms. According to Ford and Ryan (1977, p.370) "this may be due to the supposed difficulties of handling the marketing of an intangible product compared with the tangibility of the normal manufactured product. It may also be caused by the difficulties of recognising a potentially marketable technology among those possessed (and taken for granted?) by the firm.” Caves, Crookell et al. (1983) analyzed international technology transfer to foreign countries in terms of licensing and provided an argumentation that the market for technology licenses, like other markets for intangible knowledge, is susceptible to market failures resulting from five prevalent obstacles. Firstly, at the time when they published the study, they had observed that typically only very few firms are willing to license a technology they possess, while on the other hand the demand of firms that feel a specific need for a

another high profile patent case, Intel reached a US\$ 525 million settlement of a suit alleging that Intel’s Pentium family of microprocessors infringed Intergraph's patents. Cf. Gilbert and Katz (2007). In 2008, one of the first high-number infringement cases started in Europe when IP-Com sued Nokia at the German patent court in Mannheim for infringing about 1,000 patents of about 150 patent families. IP-Com, who bought the patents in 2006 from Robert Bosch GmbH, claims $€ 12$ billion damages. 
certain technology is limited. Accordingly, these few available 'pairs' lead to small-numbers bargaining conditions and thin markets. Secondly, as Caves, Crookell et al. (1983) argued, the different parties involved in a transaction have asymmetrical access to knowledge about the technology, which leads to opportunistic behaviour. Thirdly, since technologies are usually transacted that still need certain developments before they can be fully utilized or the technology may not work properly at any new location for whatever reason (e.g. missing tacit knowledge) the technology's economic performance usually remains uncertain at the time of the transaction. Aside from these specific obstacles, Caves, Crookell et al. (1983) fourthly argued that the actors involved in any transaction usually act risk averse. Since a transfer of a technology usually involves uncertainty whether the technology will perform as promised, a transaction may threaten the participants due to necessary financial investments. Finally, the preparation and contact costs involved in the transaction can be substantial. Referring to Teece (1977), Caves, Crookell et al. (1983) stated that these costs might be between 2 and 59 (average 19) percent of the recipient's total costs for the transfer, thus transaction costs reduce the attractiveness to engage in any transaction additionally. In addition, Teece (1986) noted that there are particularly difficulties in pricing intangible assets which is not at least due to their unique or at least highly specific nature.

When the issue of technology trade started to receive increasing attention by scholars at the end of the 1990s and early $21^{\text {st }}$ century, some scholars identified and discussed difficulties of technology trade in more detail. Throughout their study of technology trade, which was published in their influencing work, Arora, Fosfuri et al. (2001) identified reasons why MfT are inefficient. Major difficulties include the problems of valuing intangible assets without the presence of a market and absence of standard valuation approaches, the context dependency of each and every technology, and the stickiness of information and the opportunistic behaviour of the market actors. As consequence of the presence of these difficulties high transaction costs exist for selling technologies that lower the profit opportunities for firms that are willing to conduct transactions.

In addition, Lichtenthaler (2004) mentioned the 'only use here' syndrome that exist in several firms to a certain degree due to political discussions and interests of internal department in context of the resource allocation process. On the other hand, firms that acquire technologies often face the 'not invented here' syndrome ${ }^{23}$ which reduces their incentives to embed a technology into own products or processes that was invented elsewhere (e.g. by a competitor). Studying the market for technology, primarily in Japan, Chesbrough (2006, p.146) found that there is "no information standard for technology licensing and associated IP trade.” According to him, this absence of a standard that fails to

\footnotetext{
${ }^{23}$ Cf. e.g. Lichtenthaler and Ernst (2006), Katz and Allen (1982).
} 
provide the terms and conditions for trading IP it is difficult to compile statistics on technology trade. Without these data, it is hard for firms to know what technology is available in the market and for what price ranges. Additionally, it is very challenging to know how to value available technologies. Troy and Werle (2008, p.3) also reported that “a commonly accepted method of determining a patent's value is missing." Chesbrough (2006) further mentioned the lack of a systematic reporting of previous prices paid for external technologies. ${ }^{24}$ Several other studies (e.g. (Teece (1998), Teece (2000), Davis and Harrison (2001), Gambardella (2002), Chesborough (2003), Cesaroni, Gambardella et al. (2004), Lichtenthaler (2004), Escher (2005)) as well mentioned obstacles preventing external acquisition and exploitation activities and thus technology trade. Summarizing the existing evidence, three categories appear to reflect most of the obstacles mentioned above. These include various types of uncertainty, information asymmetry and - actually leading to - high transaction costs, although these three are intertwined and can be hardly distinguished clearly. ${ }^{25}$

\section{Emergence of Technology Market Intermediaries}

Thirdly, scattered evidence indicates that recently TMIs have emerged on the MfT representing a new type of specialized market actors (organizational innovation). OECD, BMWI et al. (2005, p.10) pointed out that recently "market intermediaries have become more numerous and diverse as demand for technology transfer and patent valuation have (has?) grown.” According to the EPO, OECD et al. (2006, p.1) "the IP marketplace is nowadays in a probe and learn period where the number of intermediaries is rising.” EPO, OECD et al. (2006) drew further attention to the rise of new business models which those intermediaries apply. Examples of TMI models mentioned in that study include partnerships or technology pools to special purpose investments vehicles, auctions, publicly traded IP indexes as well as patent value funds which aim at taking care of IP logistics issues (e.g. finding and negotiating with potential licensees) whilst filling in the financial gap needed to allow the necessary managerial efforts preceding the commercialization of new products, i.e. identifying potential licensors, establishing contacts and negotiating with them up to the closing of a transaction. According to EPO, OECD et al. (2006, p.1) these new models "make one step forward towards the development of a market for IP transfers ... [and]... contribute to the maturation of the IP market.”

\footnotetext{
${ }^{24}$ We follow the argument of Hayek (1975), who argued that only the price information on a market represents the necessary information to lead to efficient resource allocation.

${ }^{25}$ Missing a solid empirical base, we neither aim for nor do we claim that these three categories are comprehensive or exhaustive covering all obstacles that exist in IP transactions. Referring to DeGennaro (2005, p.110) "there are millions of imperfections and no structure can hope to be complete." However, we believe that the three proposed categories cover the major ones.
} 
Aside from governmental organizations, scholars from this field have as well recognized this trend. Koruna (2001) observed that with new services and instruments on the market the process of externally exploiting technologies is getting easier and thus will probably also gain more acceptance among firms. Chesbrough (2006, p.3) reported "that a small number of intermediary firms have arisen in recent years to assist in the process of identification, negotiation, and transfer of patents from one firm to another." Troy and Werle (2008, p.20) noted that "the number of intermediaries is growing, as is the propensity of firms to employ specialized intellectual property professionals. These and other actors potentially involved in patent transactions gain trading experience, experiment with different modes of trade, and invent ways to cope with uncertainty."26

However, few statistics were available to us documenting this trend by strengthening the scattered evidence. Therefore we collected own data throughout a pre-study in December 2006. Based on interviews with a range of industry experts we identified about 70 TMIs with the growth rate of those firms measured by the year of their foundation. Our results confirm the trend. An approximated exponential curve fit indicates an annual 'birth rate' of $8 \%$ of TMIs appearing on the MfT starting from $1980 .^{27}$

In context of innovation systems ${ }^{28}$, different roles of intermediaries have been described. Various scholars however used different synonyms. The functions have been discussed as third parties (Mantel and Rosegger (1987)), intermediary firms (Stankiewicz (1995)), bridgers (McEvily and Zaheer (1999), Bessant and Rush (1995)), brokers (Provan and Human (1999), Hargadon and Sutton (1997)), information intermediaries specifically associated with the exchange of information (Popp (2000)) and superstructure organizations (Lynn, Reddy et al. (1996)). However, research on intermediaries to facilitate IP transactions.

TMIs try to exploit business opportunities by matching seller and buyer for reduced transaction costs as if they would try to establish a transaction without the support of a TMI. To our knowledge so far

\footnotetext{
${ }^{26}$ We like to note that the emergence of intermediaries is not special to MfT when markets do not "clear" efficiently. E.g. in agricultural markets Klerkx and Leeuwis (2008, p.260) reported that "due to market and systemic failures, both supply side and demand side parties in this market have experienced constraints in effecting transactions and establishing the necessary relationships to engage in demand-driven innovation processes. To mitigate these constraints, a field of intermediary organizations has emerged to assist agricultural entrepreneurs to articulate demand, forge linkages with those that can provide innovation support services, and manage innovation processes."

${ }^{27}$ Counting for $80 \%$ of the TMIs, by far the majority of the TMIs seem to be based in the US clustering around two centres at the west and east coasts. While a considerable number of them are concentrated around Silicon Valley at the west coast, another cluster is concentrated at the east cost including New York and Massachusetts. The TMIs that are not based in the US are mainly European and Canadian firms. In Europe British and German firms account for the majority. Several US-based TMIs maintain regional offices in Europe, Japan, China and East Asia. A description of the sample can be found in Tietze and Barreto (2007). Founding dates could be identified for only 60 TMIs of the whole sample.

${ }^{28}$ Defined by Kuhlmann and Meyer-Krahmer (2001) as systems encompass the 'biotopes' of all those institutions which are engaged in scientific research, the accumulation and diffusion of knowledge, which educate and train the working population, develop technology, produce innovative products and processes, and distribute them.
} 
no comprehensive and systematic categorization of TMIs exists that assist specifically the IP transactions. But we learned from our pre-study by Tietze and Barreto (2007) that one can distinguish at least two types of intermediaries depending on the scope of the services they offer. ${ }^{29}$ TMIs either support the whole transaction process (e.g. auction provider) or offer particular services in certain stages of the transaction process (e.g. technology valuation experts).

Some of the fragmented, conceptual literature discussing intermediaries in the specific context of IP transactions includes Lien (1979), Czarnitzki, Licht et al. (2001), Birkenmeier (2003), Krattiger (2004) and from a practitioner point of view Millien and Laurie (2007). Furthermore, the intermediary concept is discussed in the specific context of IP transactions by e.g. Mittag (1985) discussing various forms of specialized intermediaries, Fu and Perkins (1995) who identified tasks that involve the help of 'external experts' (including evaluation, training, financial negotiations, legal/ technology / strategy negotiations, tailoring technology, approaching and identifying prospects), and Pollard (2006) who discussed the role of technology transfer intermediaries in the processes of innovation in networks involving universities, research and development centres, and business firms from an international perspective.

An example for a recently developed model to facilitate IP transactions is the public patent auction model. In spring 2006 the first widely recognized public multi-lot IP auction took place in San Francisco, US. Since then the model has gained particular interest not only in the community of IP experts. ${ }^{30}$ Following the initial auction at least twice a year IP auctions were held not only in the US but also in Europe and Asia. Sales generated through six auctions between spring 2005 and autumn 2007 accumulated to more than $€ 30$ million.

\section{Explaining recent trends - Why TMIs emerge and how they facilitate transactions}

Having observed the recent growth of the MfT, the still persisting transaction obstacles and the emergence of TMIs we were interested in examining, why do TMIs emerge and how do they impact IP transactions. In the following we propose an explanation for the emergence of TMIs. Additionally, we

\footnotetext{
${ }^{29}$ Tietze and Barreto (2007) proposed a systematization of 12 TMI types. Other, even less systematic attempts to categorize TMIs can be found in Chesbrough (2006) and from a practitioner viewpoint in Millien and Laurie (2007).

${ }^{30}$ Auctions, as one of the oldest negotiation mechanisms, appear suitable to trade assets in various fields and in multiple contexts. Traditionally, among the most prominent assets traded via auctions are art, antiques and wines. However, in recent years auctions have been applied for an increasing range of tangible (e.g. second hand industrial machinery to third world countries, real estate properties, see e.g. Azasu (2006), Shenkar and Arikan (2006)) but as well for intangible assets, including e.g. various types of services (e.g. craftsmen services for house repair, travel services, software developer services, problem solving services) or IP assets (e.g. patents, 3G licences, see e.g. Klemperer (2004), Milgrom (2005)). Furthermore, McClure (2008, p.102) argued that "the current wave of activity in the IPR market. IPR auctions have attempted to commoditize IPRs.”
} 
propose an explanation of how TMIs attempt to facilitate IP transactions and thus contribute to more economical creation of innovation. Our argumentation reflects two levels of analysis. While we take into account the market level (where transactions are conducted involving multiple actors) we further take into account the micro level of the firm (that has to manage the transactions).

\section{Why TMIs Emerge}

In order to explain the emergence of TMIs, the notion of Stigler (1951) provides a valuable argumentation. Stigler (1951) formalized the Smithian notion that specialization depends on the size of the market and thus provided a widely applied theoretical foundation with roots back to Smith (1776). Accordingly, market growth can lead to further specialization of the division of labor, i.e. to the emergence of new market actors (e.g. intermediaries) that specialize on certain dedicated tasks. Actually Coase (1937) had already argued that firms emerge when transaction costs are reduced compared to pure market coordination. Accordingly, an intermediary might exist if its activities induce a reduction of transaction costs between the market actors, thus enhance the outcome of the market.

Within his seminal paper, Stigler (1951, p.142) defined the firm "not among the markets in which it buys inputs but among the functions or processes which constitute the scope of its activity.” Stigler (1951) argued that the different processes are characterized by different average cost functions, i.e. he differentiated among three types ('falling continuously', 'rising continuously' and 'conventionally Ushaped'). Similar processes are characterized by increasing or diminishing returns. Based on the respective cost and return structure, Stigler (1951, p.143) suggested that firms abandon "functions subject to diminishing returns... [where the]... cost of the final product does not diminish with output... allowing another firm (and industry) to specialize in them to take full advantage of increasing returns." ${ }^{31}$ However, at any given time these functions, i.e. the sales of the product/service may be too small to support a specialized merchant; the output of a by-product may be too small to support a specialized fabricator; the demand for market information may be too small to support a trade journal. In these cases, the firm must then perform these functions for itself although often with poor efficiency. Stigler (1951, p.188) then argued that "with the expansion of the industry, the

\footnotetext{
${ }^{31}$ This argumentation, i.e. a forward disintegration of certain processes to specialized firms appears to be the basic argument of what is known today as the concept of 'outsourcing'. Cf. e.g. Akehurst (2008), Holcomb and Hitt (2007), Mahnke (2001). Since the early 1950s, the discussion of disintegration has carried on until today. Particularly since the mid 1990s with the increased performance of ICT and the globalisation in many industries "services previously undertaken in-house within organisations are outsourced to specialist firms" according to Akehurst (2008, p.6). Although today outsourcing is considered by many scholars to have driven the growth of business services (e.g. Martinelli (1991), Rajan and Pearson (1986)) the theory is not without critics and doubts. Some empirical studies have reached inconsistent results (e.g. Bryson, Keeble et al. (1993), Levy (1984), Stuckey (1983), Tucker and Wilder (1977)) and e.g. Perry (1989) questioned the way Stigler had defined 'specialization'.
} 
magnitude of the function subject to increasing returns may become sufficient to permit a firm to specialize in performing it.” The firm will then abandon the process (disintegrate), and a new firm will take it over. Thus, throughout an industry development disintegration might appear during a growth phase and reintegration most likely during a decline phase. The argumentation Stigler (1951) provided can be applied to explain the recent emergence of TMIs on the MfT.

We have seen that currently three phenomena can be observed on the MfT where IP transactions are commonly conducted. Firstly, currently, respectively since the last decade the MfT have been sizably growing. Secondly, firms encounter various obstacles within IP transactions. Among others uncertainty and asymmetric information lead to high transaction costs for IP transactions. Thirdly, the emergence of TMIs, as a new type of market actor that provide innovative services on the MfT. Following the notion of Stigler (1951) and the previously presented evidence we argue that the emergence of TMIs should be interpreted as a result of the first two phenomena. ${ }^{32}$

The growth of the MfT is the basis for our argumentation. Following Stigler (1951, p.189) "vertical disintegration is the typical development in growing industries" so that "specialism of firms may take the form of transactioning with a narrower range of products as well as performing fewer functions of the same range of products.” We argue accordingly that recently the trade of IP and technical knowledge on the MfT appears to have reached a sufficient size to open up business opportunities for specialized firms. Those business opportunities constitute an incentive large enough for entrepreneurs to develop specialized business models for certain parts of IP transactions resulting in the emergence of TMIs. Offering specialized services to different firms owning large technology portfolios willing to conduct many transactions, TMIs can realize economies of scale. Contracting with TMIs might thus be more economically for firms owning technologies than performing transactions solely with in-house resources. The emergence of TMIs as organizational innovation thus represents an institutional change causing firms owning technology portfolios to vertically forward disintegrate (outsource) of certain management tasks of transactions.

Furthermore, this argumentation can be strengthened by the more recent argumentation of North (1996, p.3). He argued that the "constraints imposed by the institutional framework (together with the other constraints) define the opportunity set and therefore the kind of organizations that will come into existence.” Transferring this cause-effect relation to our case, we can argue that the growth of the market has changed (incrementally) the institutional setting in the way that the growing market

\footnotetext{
${ }^{32}$ Although the relationship probably should not be understood as a unidirectional causal relationship. A more meaningful assumption would rather be that the causal relationship between these phenomena must be seen as mutual reinforcing.
} 
potential enabled business opportunities. These opportunities became incentives for entrepreneurs ${ }^{33}$ to develop new models to facilitate transactions (service innovations) that subsequently led to the emergence of TMIs as novel organizational type (organizational innovation) with further impact on the innovation system. Following North (1996, p.5) these entrepreneurs "assess the gains to be derived from recontracting within the existing institutional framework compared to the gains from devoting resources to altering that framework.” Interacting with firms that pursue transactions, this change then led to the evolution of "alternative patterns of behavior consistent with their newly perceived evaluation of costs and benefits.” Thus, the emergence of TMIs can lead to the change of governance structures of market transactions, i.e. the way how firms manage open innovation transactions.

We argue further that this impact is cyclical and feedback on the obstacles that persist within technology transactions. Hopefully, depending on any specific 'new' transaction model, this impact will be positive in sum (i.e. lower overall obstacles) in order to facilitate transaction efficiency, having in mind that the nature of the 'new' transaction models might impose additional obstacles onto transactions (e.g. particularly due to increased complexity and coordination efforts). Increasingly efficient transactions would then gradually support firms to pursue open innovation through exchanging technological assets more frequently within networks. Thus, TMIs ultimately can contribute to more efficient cumulative creation of innovation through more economical exchange of technologies.

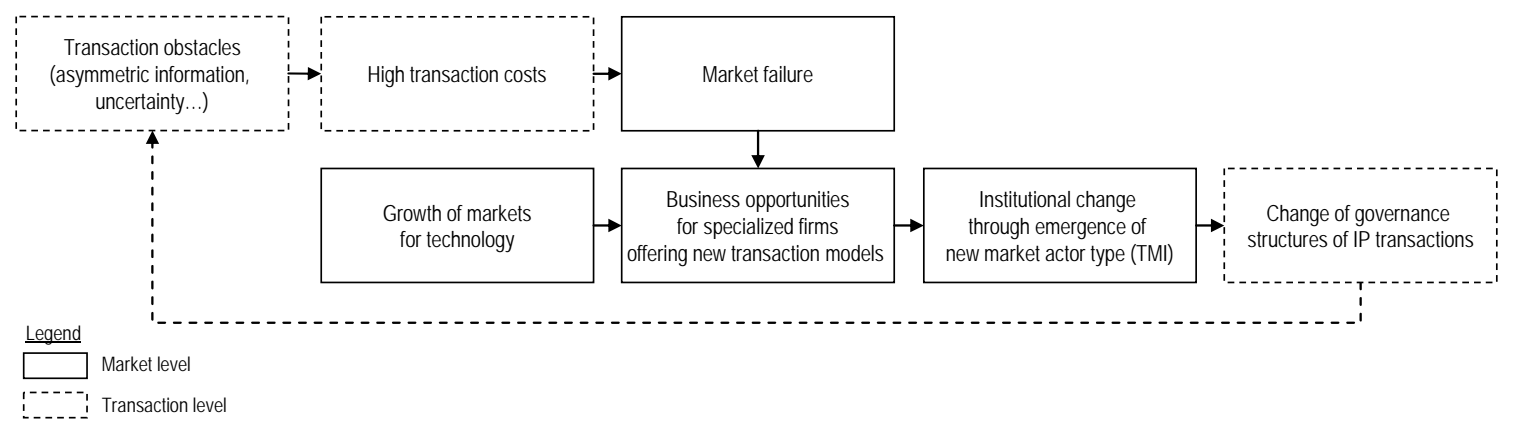

Figure 2: Why TMIs emerge and their impact on IP transactions

North (1996, p.9) provided a similar argument illustrating how "institutions, organizations, and the mental models of the actors interact to produce institutional change.” In an example (of American colonial history) he argued in line with Chandler (1977) that "as organizations evolved to take advantage of opportunities they became more productive ... and gradually they also altered the

\footnotetext{
${ }^{33}$ Similar to the argument of Schumpeter (2006), North (1996)sees the entrepreneur as the 'source for change'.
} 
institutional framework.” A similar evolution (spiral of feedback circles) can be argued to happen on the MfT. TMIs impact the traditional division of labor and gradually lead to changes in the transaction processes that can be perceived as changes in the informal institutions (e.g. behavioural change in the management of transactions) and thus as institutional innovation. Following the argumentation of North (1996) institutional innovations might lower the costs of transacting and permit capturing more of the gains from trade and hence permit the expansion of markets. Therefore, North (1996, p.22) argued that the "continuous interaction between institutions and organizations in the economic setting of scarcity and hence competition is the key to institutional change." Figure 2 illustrates our argumentation taking into account both the micro level of the firm and the market level.

However, it appears unlikely that firms will be able to disintegrate all management tasks to TMIs which they have traditionally performed in-house. Referring to Stigler (1951), firms will preferably outsource those tasks that do not represent increasing returns or diminishing costs, but retain tasks which might include further the governance (coordination and communication) of the transaction process and tasks where the technology owner needs to deliver technical, economic and legal information about the technology (e.g. as input to the due diligence to potential buyer). Firms will only agree to forward disintegration if either the earnings from successful transactions are significantly higher, the transaction success rates increase significantly or the transaction costs (including fees charged by TMIs) are significantly reduced. According to Stigler (1951, p.143) specialized firms (TMIs) "cannot charge a price for the process higher than the average cost of the process to the firms which are abandoning it.” Only if TMIs are able to prove a sustainable business case, their business models will survive in the long run.

\section{How TMIs impact IP Transactions}

Having proposed an explanation for the emergence of TMIs on the MfT, we continue to propose an explanation of how TMIs attempt to make technology transactions more economical on the micro level of the firm. The argumentation provided by Williamson (1979, p.234) based on Williamson (1975) can be applied to explain the impact of TMIs on the way how transactions are managed.

Williamson (1979, p.239) argued that "governance structures - the institutional matrix within which transactions are negotiated and executed - vary with the nature of the transaction.” According to Williamson (1979) the choice of the governance structure depends mainly on the asset specificity and the transaction frequency of a traded asset. Asset specificity refers to "the degree to which an asset can be redeployed to alternative uses and by alternative users without sacrifice of productive value” according to Williamson (1991, p.281). He identifies six types of asset specificity: 1) site specificity, 
which refers to the advantage of two or more assets jointly located to each other; 2) physical asset specificity, which refers to physical equipment customized to each other; 3) human asset specificity, which refers to training and learning by doing; 4) brand name capital; 5) dedicated assets, which are "discrete investments in general purpose plant that are made at the behest of a particular customer"; and 6) temporal specificity. Not just on theoretical argument, but further on an empirical basis Anderson and Coughlan (1987) found that asset specificity is positively related to e.g. the use of integrated channels in marketing. ${ }^{34}$ In comparison to asset specificity, transaction frequency has received far less treatment in the empirical literature (Rindfleisch and Heide (1997)). Empirical research has been largely unable to confirm (or refute) the effects of transactional frequency on governance modes. Some empirical studies showed no positive association between transaction frequency and organizational mode (Anderson and Schmittlein (1984); Anderson (1985); Maltz (1994)), while other studies dichotomized transaction frequency into one-time versus recurring exchanges and do find a significant relationship (John and Weitz (1989); Klein, Frazier et al. (1990)).

Thus, the crucial investment distinction is to what degree transaction-specific (nonmarketable) expenses are incurred. According to Williamson (1979) assets that are unspecialized among users pose few hazards, since buyers in these circumstances can easily turn to alternative sources, and suppliers can sell output intended for one order to other buyers without difficulty. Non-marketability problems arise when the specific identity of the parties has important cost-bearing consequences. Williamson (1979) referred to transactions of this kind as 'idiosyncratic'. Occasionally even the identity of the parties is important from the outset, as when a buyer induces a supplier to invest in specialized physical capital of a transaction-specific kind. Inasmuch as the value of this capital in other uses is, by definition, much smaller than the specialized use for which it has been intended, the supplier is effectively 'locked into’ the transaction to a significant degree.

Williamson (1979, p.239) then concluded that that while "simple governance structures should be used in conjunction with simple contractual relations and complex governance structures reserved for complex relations seems generally sensible. Use of a complex structure to govern a simple relation is apt to incur unneeded costs, and use of a simple structure for a complex transaction invites strain.” Williamson (1979, p.247) proposed a typology of governance structures. He considered three broad types of governance structures: non-transaction-specific, semi-specific, and highly specific. The market is the classic non-specific governance structure within which 'faceless' buyers and sellers meet for an instant to exchange standardized goods at equilibrium prices. By contrast, highly specific structures are tailored to the special needs of the transaction, where identity clearly matters. Semi-

\footnotetext{
${ }^{34}$ For a recent discussion of asset specificity see Ruzzier (2009).
} 
specific structures, naturally, fall in between. Thus, to a large extent the choice of any governance structure depends on the asset specificity, i.e. whether an asset is a commodity or highly specific.

Following the definition for asset specificity of Williamson (1979), technologies and particular patents must be understood as assets with a high specificity. Patents constitute an intangible asset, which are commonly harder to value than tangible assets. Particular the unique nature of patents makes it even more difficult to value them. Reitzig (2003, p.18) concluded that "it is known that the value of a patent is highly idiosyncratic." These characteristics of patents as traded assets are reflected in the governance structures commonly employed when trading patents, as suggested by Williamson (1979). Various obstacles have permitted efficient transactions on the MfT and led over long time to the idiosyncratic governance structures as preferred ('traditional') transaction model. Most transactions were conducted through bilateral negotiations in private (closed) settings. These bilateral transactions allowed for contracts to be individually adjusted to specific needs and requirements of the involved actors, i.e. as idiosyncratic transactions take the nature of relational contracts.

On firm level, this argumentation is in line with empirical observations of the 'traditional' transaction models, respectively management process models (e.g. the 'external technology deployment process' proposed by Escher (2005) and the 'external technology commercialization process' proposed by Lichtenthaler (2006)). Both process models are similar to a certain extent, but bear some differences. Lichtenthaler (2006) defined two phases that accompany the whole process and specified explicit subphases. Escher (2005) however in his process included certain key decisions that have to be prepared and taken. However, neither of the two ETE processes accounted for the integration of TMIs but rather indicated bilateral, direct transactions between IP owners and potential buyers that account for the high asset specificity and low number of IP transactions that occurred traditionally in many firms. How do these processes change with the emergence of TMIs?

Having argued that the emergence of TMIs as organizational innovation constitutes an institutional change on the MfT according to North (1996), we argue further that TMIs have an impact on the governance structures of transactions and thus the way how transactions are management by firms. Following the notion of Williamson (1979, p.234), TMIs “develop alternative institutional modes for organizing transactions”. One way, how TMIs change governance structures become obvious looking closer at newly developed transaction models. For instance, having conducted a comparative analysis of governance structures of IP auctions, we know that auctions attempt to facilitate IP transactions efficiency through two major changes in the governance structures. Firstly, the sellers and buyers of IP are not anymore directly connected. Thus the nature of the transaction becomes 'indirect' and in the case of IP auctions even multilateral (involving various bidders) in contrast to the bilateral nature of the 'traditional' transactions. Secondly, IP auctions implement more standardized governance 
structures for IP transactions through the use of standardized legal frameworks (e.g. using standardized due diligence procedures, standardized contracts, and lump sump payments). Thus, IP auctions can be seen to employ at least semi-specific governance structures while attempting to trade highly specific assets as 'spot market transactions'. The argumentation links to Williamsons discussion (1979, p.108) of "governance costs as a function of asset specificity" and is further illustrated in Figure 3. Consequently, from the 'exogenous' adjustment of the governance structure, the question arises: Are the new governance structures of e.g. auction still suitable for transactions of highly specific IP assets?

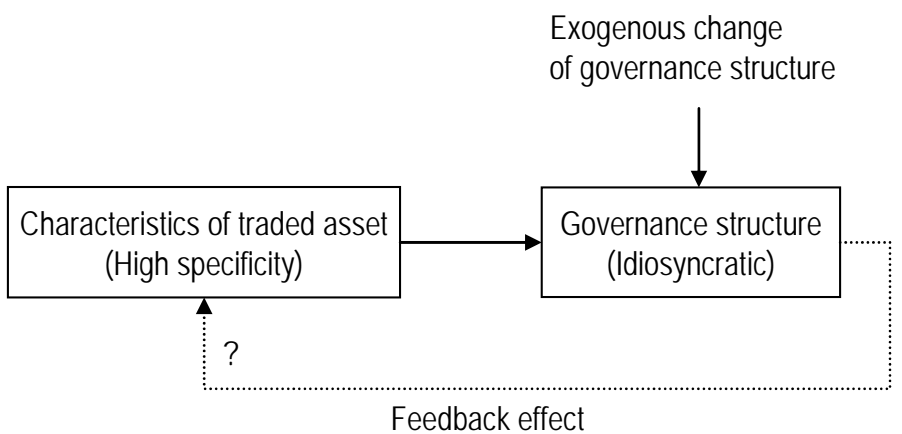

Figure 3 - How are traded asset characterized that suit new governance structures

The answer to this question is neither trivial nor can it be answered in general, wherefore it is out of the scope of this paper. But certainly, it can and should not be answered for all technologies and particularly patents similarly. Although patents are unique by definition, certain patents still share some characteristics. For instance, different patents can be in an early stage of their technology life cycle, can have a similar legal scope (breath) or similar degree of technical complexity. Thus, while certain types of patents could be suitable to be auctioned, firms might exploit other patents more economically through other channels. To explore the question which exploitation channels are suitable for which type of patents is further subject to our ongoing research.

\section{Conclusions}

To conclude, recent market developments force firms to continuously innovate. However, innovation is a cumulative process that increasingly requires the combination of internally developed technologies with externally acquired ones, particularly for increasingly complex products. Firms increasingly follow the paradigm of 'open innovation' to maximize their returns of R\&D investments, wherefore external technology acquisition and exploitation is becoming increasingly important. Although growing MfT indicate increasing trade activities, various obstacles still prohibit efficient transactions. 
The current status can hardly be considered to be supportive to innovation and firm growth. Currently TMIs emerge as a new type of markets actors.

Following our argumentation TMIs emerge as organizational innovations developing innovative services impacting on the 'traditional' division of labor among firms engaging into technology transactions. The emergence of TMIs causes an institutional change, i.e. a forward disintegration of the technology owners who 'outsource' certain tasks to TMIs. This 'new' division of labor between technology owners, buyers and TMIs on market level has an impact on the governance structures of IP transactions on the micro level of the firm, i.e. how firms manage IP transactions. The new transaction models developed by TMIs attempt to facilitate IP transactions by circumventing or diminishing the present transaction obstacles. Their involvement impacts the nature of the transactions shifting it from 'direct' to 'indirect' governance structures. For instance, for IP auctions we have argued that in spite of the obstacles inherent from the nature of patents and the protected technical inventions, the auction model attempts to shift the 'traditional' governance structures from highly specialized, individually designed 'idiosyncratic' transactions towards more standardized governance structures diminishing transaction costs.

However, we doubt that all technologies and patents can be traded though any of the newly developed transaction models at a similar level of efficiency. Indications at least exist that it might not be the case. It seems as for instance IP auctions are suitable only for certain types of patents. Therefore, we continue to investigate how patent auctions can facilitate to develop inventions into innovation more economically and for which types of patents they constitute a suitable exploitation channel.

Whether IP auctions specifically will become a successful model to facilitate IP transactions remains an open question. Similarly, it is the case for other new models. If TMIs develop models that employ novel governance structures that are not suitable, we will see them disappearing or at least to be significantly adjusted.

If certain models developed by TMIs prove to be suitable to trade certain patents, then we will see an evolution on the MfT resulting in further differentiation of exploitation models. Consequently, with an increasing number of exploitation channels, innovation and IP managers will face the increasing need to decide which exploitation channel to decide for any particular patent of their portfolio when carrying out open innovation.

How TMIs, and IP auctions as a particular novel model impact IP transactions and whether they contribute to more efficient market transactions remains to be seen and is subject to our ongoing research where we derive further implications for whom believe are the main stakeholders, i.e. 
particularly top level management positions concerned with IP and innovation strategy of technology based firms, TMIs themselves, but further policy makers concerned with innovation policy.

\section{Acknowledgements}

The authors would like to thank Ove Granstrand, Raymund Werke, Rajnish Tiwari and Alexandra Hüner for their valuable comments. We acknowledge the financial support from the European Regional Development Fund, the Awapatent Foundation for the Promotion of Scientific Research in the area of Intellectual Property Rights and the KühneSchool for Logistics and Management.

\section{Bibliography}

Aghion, P., C. Harris, et al. (2001). "Competition, imitation and growth with step-by-step innovation." The Review of Economic Studies 68(3): 467-492.

Akehurst, G. (2008). "What do we really know about services?" Service Business 2(1): 1-15.

Anderson, E. (1985). "The salesperson as outside agent or employee: a transaction cost analysis." Marketing Science 4(3): 234-254.

Anderson, E. and A. T. Coughlan (1987). "International market entry and expansion via independent or integrated channels of distribution." The Journal of Marketing: 71-82.

Anderson, E. and D. C. Schmittlein (1984). "Integration of the sales force: an empirical examination." The Rand Journal of Economics 15(3): 385-395.

Arora, A., A. Fosfuri, et al. (2001). Markets for technology: the economics of innovation and corporate strategy. Cambridge, Mass., MIT Press.

Arora, A. and R. Merges (2004). "Specialized supply firms, property rights and firm boundaries." Industrial and Corporate Change(13): 451-475.

Athreye, S. and J. Cantwell (2007). "Creating competition? Globalisation and the emergence of new technology producers." Research Policy 36(2): 209-226.

Azasu, S. (2006). Auctions in the Real Estate Market - A Review. Working Paper, Department of Real Estate and Construction Management, Royal Institute of Technology.

Bessant, J. and H. Rush (1995). "Building bridges for innovation: the role of consultants in technology transfer." Research Policy 24 97-114.

Bessy, C. and E. Brousseau (1998). "Technology licensing contracts features and diversity." International Review of Law and Economics 18: 451-490.

Birkenmeier, B. (2003). Externe Technologie-Verwertung: Eine komplexe Aufgabe des Integrierten TechnologieManagements. No. 15240. Zurich, ETH.

Bryson, J. R., D. Keeble, et al. (1993). "The creation, location and growth of small business service firms in the United Kingdom." Service Industries Journal 13(2): 118-131.

Budd, C., C. Harris, et al. (1993). "A model of the evolution of duopoly: Does the asymmetry between firms tend to increase or decrease?" The Review of Economic Studies 60(3): 543-573.

Caves, R. E., H. Crookell, et al. (1983). "The imperfect market for technology licenses." Oxford Bulletin of Economics and Statistics 45(3): 249.

Ceccagnoli, M., S. J. H. Graham, et al. (2009). "Firm Reliance on External Technology in the Pharmaceutical Industry."

Cesaroni, F., A. Gambardella, et al. (2004). R\&D, innovation and competitiveness in the European chemical industry. Boston, Mass., Kluwer Academic. 
Chandler, A. D. (1977). The visible hand: The managerial revolution in American business, Belknap Press.

Chang, H. F. (1995). "Patent scope, antitrust policy, and cumulative innovation." The RAND Journal of Economics 26(1): 34-57.

Chesborough, H. (2003). "The era of open innovation." MIT Sloan Management Review.

Chesbrough, H. (2003). "The logic of open innovation: managing intellectual property." California Management Review 45(3): 33-58.

Chesbrough, H. (2006). Emerging secondary markets for Intellectual Property, Research Report to National Center for Industrial Property Information and Traning (NCIPI).

Chesbrough, H. W. (2003). Open Innovation. The New Imperative for Creating and Profiting from Technology. Boston, Harvard Business School Press.

Coase, R. H. (1937). "The Nature of the Firm." Economica 4 (16): 386-405.

Czarnitzki, D., G. Licht, et al. (2001). "Rolle und Bedeutung von Intermediären im Wissens- und Technologietransfer." ifo Schnelldienst 4: 40-49.

Davis, J. L. and S. S. Harrison (2001). Edison in the boardroom : how leading companies realize value from their intellectural assets. New York, Wiley.

DeGennaro, R. P. (2005). "Market Imperfections " Journal of Financial Transformation 14.

Edvinsson, L. and P. H. Sullivan (1996). "Developing a Model for Managing Intellectual Capital." European Management Journal 14(4): 356-363.

Elton, J., B. Shah, et al. (2002). "Intellectual Property: Partnering for Profit." Mc Kinsey Quarterly(Special Edition - Technology): 59-67.

Engerman, S. L. (2003). Finance, intermediaries, and economic development. Cambridge [u.a.], Cambridge Univ. Press.

EPO, OECD, et al. (2006). Patents: realising and securing value - Executive summary, London.

Escher, J.-P. (2005). Technology Marketing in Technology-based Enterprises - The Process and Organization Structure of External Technology Deployment. Zurich, Swiss Federal Institute of Technology Zurich.

Ford, D. and C. Ryan (1977). "The Marketing of Technology." European Journal of Marketing 11(6): 369-383.

Fu, S. and D. S. Perkins (1995). "Technology licensors and licensees: who they are, what resources they employ, and how they feel." International Journal of Technology Management 10(7/8): 907-920.

Gambardella, A. (2002). "Successes and failures in the markets for technology." Oxford Review of Economic Policy 18(1): 52-62.

Gambardella, A., P. Giuri, et al. (2007). "The Market for Patents in Europe." Research Policy(36): 1163-1183.

Gambardella, A., P. Giuri, et al. (2006). Study on evaluating the knowledge economy : what are patents actually worth? The value of patents for today's economy and society. Brussels, European Commission, DirectorateGeneral for Internal Market.

Gilbert, R. J. and M. L. Katz (2007). "Efficient division of profits from complementary innovations." Innovations.

Gorton, G. and A. Winton (2002). FINANCIAL INTERMEDIATION. NBER WORKING PAPER SERIES. NATIONAL BUREAU OF ECONOMIC RESEARCH

1050 Massachusetts Avenue

Cambridge, MA 02138.

Granstrand, O. (2000). "The Shift Towards Intellectual Capitalism - the Role of Infocom Technologies." Research Policy 29(9): 1061-1080.

Granstrand, O. (2003). Innovation and Intellectual Property. DRUID Summer Conference 2003 on Creating, Sharing and Transferring Knowledge, Copenhagen.

Granstrand, O. (2004). "The economics and management of technology trade: towards a pro-licensing era?" International Journal of Technology Management 27(2,3): 209.

Granstrand, O., E. Bohlin, et al. (1992). "External Technology Acquisition in large multi-technology corporations." R\&D Management 22(2).

Granstrand, O. and S. Sjölander (1990). "Managing Innovation in Multi-Technology Corporations." Research Policy 19: 35-60. 
Green, J. R. and S. Scotchmer (1995). "On the division of profit in sequential innovation." The RAND Journal of Economics 26(1): 20-33.

Grindley, P. C. and D. J. Teece (1997). "Managing Intellectual Capital - Licensing and Cross-Licensing in Semiconductors and Electronics." California Management Review 39(2): 8-41.

Gu, F. and B. Lev (2000). "Markets in Intangibles: Patent Licensing." Available at SSRN: http://ssrn.com/abstract=275948.

Gu, F. and B. Lev (2001). Markets in intangibles: Patent licensing.

Hargadon, A. and R. I. Sutton (1997). "Technology brokering and innovation in a product development firm." Administrative Science Quarterly(42): 718-749.

Harris, C. and J. Vickers (1987). "Racing with uncertainty." The Review of Economic Studies 54(1): 1-21.

Hayek, F. A. v. (1975). "Die Anmaßung von Wissen." ORDO. Jahrbuch für die Ordnung von Wirtschaft und Gesellschaft, Stuttgart.

Herstatt, C. (2007). Management der frühen Innovationsphasen : Grundlagen - Methoden - Neue Ansätze. Wiesbaden, Gabler.

Herstatt, C. and E.v.Hippel (1998). Developing New Products via the Lead User Method. Managing Strategic Innovation and Change. M. Tushman and P. Anderson. Oxford (USA).

Holcomb, T. R. and M. A. Hitt (2007). "Toward a model of strategic outsourcing." Journal of Operations Management 25(2): 464-481.

Holmström, B. and J. Roberts (1998). "' The Boundaries of the Firm Revisited"." Journal of Economic Perspectives 12: 73-94.

Institut der deutschen Wirtschaft Köln (2006). Das Innovationsverhalten der technikaffinen Branchen Forschung, Patente und Innovationen. Köln, Studie im Auftrag des Verein deutscher Ingenieure (VDI): 28.

John, G. and B. Weitz (1989). "Salesforce compensation: An empirical investigation of factors related to use of salary versus incentive compensation." Journal of Marketing Research 26(1): 1-14.

Katz, R. and T. J. Allen (1982). "Investigating the Not Invented Here (NIH) syndrome: A look at the performance, tenure, and communication patterns of 50 R \& D Project Groups." R\&D Management 12(1): 7-20.

Klein, S., G. L. Frazier, et al. (1990). "A transaction cost analysis model of channel integration in international markets." Journal of Marketing Research 27(2): 196-208.

Klemperer, P. (2004). Auctions : theory and practice. Princeton, NJ, Princeton Univ. Press.

Klerkx, L. and C. Leeuwis (2008). "Matching demand and supply in the agricultural knowledge infrastructure: Experiences with innovation intermediaries." Food Policy 33(3): 260-276.

Kline, D. (2003). "Sharing the corporate crown jewels." MIT Sloan Management Review 44(3): 89-93.

Koruna, S., Jung, (2001). External Technology Commercialization: Policy Guidelines. Portland International Conference on Management of Engineering and Technology (PICMET). D. F. Kocaoglu, Anderson, T. R. Portland: 12.

Krattiger, A. F. (2004). "Financing the Bioindustry and Facilitating Biotechnology Transfer." IP Strategy Today (8).

Kuhlmann, S. and F. Meyer-Krahmer (2001). "Internationalisation of Innovation, Interdependence and Innovation Policy for Sustainable Development." Innovation, Economic Progress and the Quality of Life: 86.

Lamoreaux, N. and K. Sokoloff (1998). Inventors, firms, and the market for technology: US manufacturing in the late nineteenth and early twentieth centuries. Learning by Firms, Organizations, and Nations. N. Lamoreaux, Raff, D., Temin, P. Chicago, University of Chicago Press: 19-60.

Lang, J. C. (2001). "Management of intellectual property rights: Strategic patenting." Journal of Intellectual Capital 2(1): 8-26.

Levy, D. (1984). "Testing Stigler's Interpretation of" The Division of Labor is Limited by the Extent of the Market"." The Journal of Industrial Economics: 377-389.

Lichtenthaler, E. (2004). "Organising the external technology exploitation process: current practices and future challenges." International Journal of Technology Management 27(2/3).

Lichtenthaler, U. (2005). "External commercialization of knowledge: Review and research agenda." International Journal of Management Reviews 7(4): 231-255. 
Lichtenthaler, U. (2006). Leveraging knowledge assets: success factors of external technology commercialization. Wiesbaden, DUV.

Lichtenthaler, U. and H. Ernst (2006). "Attitudes to externally organising knowledge management tasks: a review, reconsideration and extension of the NIH syndrome." R\&D Management 36(4).

Lichtenthaler, U. and H. Ernst (2006). "Attitudes to externally organising knowledge management tasks: a review, reconsideration and extension of the NIH syndrome." R\&D Management 36(4): 367-386.

Lichtenthaler, U. and H. Ernst (2006). "Developing reputation to overcome the imperfections in the markets for knowledge." Research Policy 36: 37-55.

Lien, A. P. (1979). "Acquiring and Selling Technology: The Role of the Middleman." Research Management 22(3, May): 29-31.

Lynn, L. H., N. M. Reddy, et al. (1996). "Linking technology and institutions: the innovation community framework." Research Policy(25): 91-106.

Mahnke, V. (2001). "The process of vertical dis-integration: an evolutionary perspective on outsourcing." Journal of Management and Governance 5(3): 353-379.

Maltz, A. B. (1994). "Outsourcing the warehousing function: economic and strategic considerations." Logistics and Transportation Review 30(3): 245-266.

Mantel, S. J. and G. Rosegger (1987). The role of third-parties in the diffusion of innovations: a survey. Innovation: Adaptation and Growth. R. Rothwell and J. Bessant. Amsterdam, Elsevier: 123-134.

Martinelli, F. (1991). A demand-oriented approach to understanding producer services. The changing geography of advanced producer services. P. W. Daniels and F. Moulaert. London: Belhaven Press.

Mazzoleni, R. and R. R. Nelson (1998). "Economic Theories about the Benefits and Costs of Patents." Journal of Economic Issues 32(4): 1031-1033.

McClure, I. D. (2008). "Commoditizing Intellectual Property Rights: The Practicability of a Commercialized and Transparent International IPR Market and the Need for International Standards." Buffalo Intellectual Property Law Journal 6: 1.

McEvily, B. and A. Zaheer (1999). "Bridging ties: a source of firm heterogeneity in competitive capabilities." Strategic Management Journal(20): 1133-1156.

Milgrom, P. (2005). Putting auction theory to work. Cambridge Cambridge Univ. Press.

Millien, R. and R. Laurie (2007). Established and Emerging IP Business Models. The 8th annual Sedona conference on patent litigation. Sedona, AZ.

Mittag, H. (1985). Technologiemarketing - Die Vermarktung von industriellem Wissen unter besonderer Berücksichtigung des Einsatzes von Lizenzen Bochum, Studienverlag Dr. N. Brockmeyer.

Murray, F. and S. O’Mahony (2007). "Exploring the foundations of cumulative innovation: Implications for organization science." Organization Science 18(6): 1006-1021.

North, D. (1996). "Institutional change: a framework of analysis." Social Rules: Origin, Character, Logic, Change: 189.

O'Donoghue, T. (1998). "A patentability requirement for sequential innovation." RAND Journal of Economics 29(4): 654-679.

OECD, BMWI, et al. (2005). Intellectual property as an economic asset: key issues in valuation and exploitation, Berlin.

Owen-Smith, J. and W. W. Powell (2003). "The expanding role of university patenting in the life sciences: assessing the importance of experience and connectivity." Research Policy 32(9): 1695-1711.

Pénin, J. (2008). "More open than open innovation? Rethinking the concept of openness in innovation studies." Working Papers of BETA.

Penrose, E. (1951). The Economics of the International Patent System. Baltimore, MD, John Hopkins University Press.

Perry, M. K. (1989). Vertical Integration: Determinants and effects. Handbook of Industrial Organization. R. Schmalensee and R. D. Willig. Amsterdam: North Holland.

Polanyi, M. (1966). The tacit dimension. Garden City, NY, Doubleday.

Pollard, D. (2006). "Innovation and Technology Transfer Intermediaries: A Systemic International Study." Advances in Interdisciplinary Studies of Work Teams: 137-174. 
Popp, A. (2000). "'Swamped in information but starved of data': information and intermediaries in clothing supply chains." Supply Chain Management Science(5): 151-161.

Powell, W. W., K. W. Koput, et al. (1996). "Interorganizational collaboration and the locus of innovation: Networks of learning in biotechnology." Administrative science quarterly 41(1).

Powell, W. W. and K. Snellman (2004). "The knowledge economy."

Provan, K. G. and S. E. Human (1999). Organizational learning and the role of the network broker in small-firm manufacturing networks. Interfirm Networks: Organization and Industrial Competitiveness. A. Grandori. London, Routledge: 185-207.

PWC (2007). Exploiting intellectual property in a complex world.

Quinn, J. B. (2000). "Outsourcing innovation: the new engine of growth." Sloan Management Review 41(4): 1328.

Rajan, A. and R. Pearson (1986). UK occupations and employment trends to 1990. Guildford: Butterworth.

Reitzig, M. (2003). "What determines patent value? Insights from the semiconductor industry." Research Policy 32 13-26.

Reitzig, M. (2004). "Strategic Management of Intellectual Property." Sloan Management Review(Spring).

Rigby, D. and C. Zook (2002). "Open-market innovation." Harvard Business Review 80(10): 80-93.

Rindfleisch, A. and J. B. Heide (1997). "Transaction cost analysis: past, present, and future applications." The Journal of Marketing 61(4): 30-54.

Roos, J., G. Edvinsson, et al. (1997). Intellectual Capital - Navigating in the New Business Landscape. London, Macmillan Press Ltd.

Rosenkopf, L., A. Metiu, et al. (2001). "From the bottom up? Technical committee activity and alliance formation." Administrative Science Quarterly 46(4): 748-772.

Ruzzier, C. A. (2009). "Asset Specificity and Vertical Integration: Williamson's Hypothesis Reconsidered." Harvard Business School Working Paper 09-119.

Scherer, F. M. and D. Ross (1990). Industrial market structure and economic performance. Boston, Mass. [u.a.], Houghton Mifflin.

Schmookler, J. (1966). Invention and economic growth, Harvard University Press Cambridge, MA.

Schumpeter, J. A. (2006). Theorie der wirtschaftlichen Entwicklung. Berlin, Duncker \& Humblot (Reprint of 1st Edition;1912).

Scotchmer, S. (1991). "Standing on the shoulders of giants: cumulative research and the patent law." The Journal of Economic Perspectives 5(1): 29-41.

Sheehan, J., C. Martinez, et al. (2004). Understanding Business Patenting and Licensing: Results of a Survey. Patents, Innovation and Economic Performance. OECD Conference Proceedings: 89-11.

Shenkar, O. and I. Arikan (2006). Auctions in Ohio Real Estate.

Shulman, S. (2003). "Big Ivory Takes License." Technology Review April: 77.

Smith, A. (1776). The Wealth of Nations, Hayes Barton Press.

Stankiewicz, R. (1995). The role of the science and technology infrastructure in the development and diffusion of industrial automation in Sweden. Technological Systems and Economic Performance: The Case of Factory Automation. B. Carlsson. Dordrecht, Kluwer: 165-210.

Stigler, G. J. (1951). "The devision of labor is limited by the extent of the market." Journal of Political Economy: 185-193.

Stuckey, J. A. (1983). Vertical integration and joint ventures in the aluminum industry, Harvard Univ Pr.

Sullivan, P. H. (2000). Value-driven intellectual capital : how to convert intangible corporate assets into market value. New York, Wiley.

Teece, D. J. (1977). "Technology transfer by international firms: the resource cost of transferring technological know-how." Economic Journal 87: 242-261.

Teece, D. J. (1981). "The market for know-how and the efficient international transfer of technology." Annaly of the Academy of Political and Social Science 458: 81-96.

Teece, D. J. (1986). "Profiting from technological innovation: implications for integration, collaboration, licensing and public policy." Research Policy(15): 285-305. 
Teece, D. J. (1989). "Inter-organizational requirements of the innovation process." Managerial and Decision Economics 10: 35-42.

Teece, D. J. (1998). "Capturing Value from Knowlege Assets." California Management Review 40(3): 55-79.

Teece, D. J. (1998). Economic performance and the theory of the firm, Edward Elgar Pub.

Teece, D. J. (2000). Managing intellectual capital : organizational, strategic, and policy dimensions. Oxford, Oxford University Press.

Terwiesch, C. and K. Ulrich (2008). Innovation and the Boundaries of the Firm, Chapter.

Tietze, F. and A. Barreto (2007). Intellectual Property Monetization: The Market and its Business Models. Institute for Technology and Innovation Management. Hamburg, Hamburg University of Technology.

Troy, I. and R. Werle (2008). Uncertainty and the Market for Patents, MPIfG.

Tschirky, H. and S. Koruna (1998). Technologie-Management: Idee und Praxis. Zürich, Orell Füssli, Verl. Industrielle Organisation.

Tucker, I. B. and R. P. Wilder (1977). "Trends in vertical integration in the US manufacturing sector." The Journal of Industrial Economics: 81-94.

Williamson, O. E. (1975). "Markets and hierarchies, analysis and antitrust implications."

Williamson, O. E. (1979). "Transaction-cost economics: the governance of contractual relations." The journal of Law and Economics 22(2): 233.

Williamson, O. E. (1991). "Comparative economic organization: The analysis of discrete structural alternatives." Administrative science quarterly 36(2). 